\title{
磐井丘陵の地形
}

\section{阿子島 功**}

低い丘陵状をなす侵蝕面の形成過程は，必ずしも明らかにされていない．丘陵地の地形発達史の一事例と して，北上川中下流域の低い侵蝕面の形成過程とその時期を検討した。

1）鮮新統の堆積盆のほぼ縁辺に分布している最高位の段丘面の高度は, 北上川本流や佐沼低地に面して 海抜 $200 \mathrm{~m}$ であり，これより低い侵蝕面群は，段丘面群と等しく，第四紀の基準面変化のうちで形成された， まず, 地盤運動に注目しつつ, 胆沢台地や佐沼低地の段丘群の相互の対比を試み, 臨海地域をふくむ当地域 の基準面変化を考察した.

2）磐井丘陵東半部の丘陵頂面の起源については諸説あり，この検討は小起伏侵蝕面の成因の一事例をあ たえた。

3）小起伏侵蝕面群は，かつて段丘面など平坦面が存在し，これが次位の基準面に応ずる支谷によって解 体されたときに生じたとみられるものと，岩質に支配されているものとがある，

4）当地域の地形発達史の試案を述べ, あわせて基準面変動史のうちで狐禅寺峡谷の成因を論じた.

\section{Iはしがき}

日本各地の低い丘陵地の丘陵頂面は, 洪積統の堆

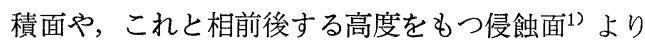
なっており，海水準変動や構造運動の背景をも加味 した，その地史的時代論が述べられている2). しか し，このうち小起伏侵蝕面の形成過程は必ずしも明 らかではなく，現在みられる侵蝕面の高度をもって その侵蝕面の形成時（層位的上限）における高度と 認めることの適否，また侵蝕面相互の地形的不整合 の認定 ${ }^{3)}$ などは常に論議され，侵蝕面の編年にあた っては残された問題が多い.

$$
\text { よって，ここでは周辺に段丘面がよく発達してお }
$$

り, Local base level の変化とその時代が明らかに
なり得る地域において，この侵蝕小起伏面の形成過 程が地形発達史のうちに組み入れられることが必要 と考えられた.

磐井丘陵は仙台平野の北縁にあって，北上川下流 域の佐沼低地の段丘群や同中流域の胆沢台地など周 辺に段丘がよく発達し，位置的にも第三紀にひきつ ゔく一連の構造運動と，第四紀の海水準変動との影 響を被ったことが予想される地域である.

\section{II 地形・地質概観}

宮城・岩手両県の県境付近にかけて，春梁の一部 をなす栗駒火山（高度 $1628 \mathrm{~m}$ ）の東斜面と, 北上山 地南端部の西斜面との間に，主に中新統・鮮新統か らなる低い丘陵が広く発達している。この丘陵は復

* 本稿は, 東北地理学会 1968 年度春季学術大会で発表したものをまとめた.

** 東北大学大学院

1）以下述べる侵蝕面は，三野（1942）のいう侵蝕平坦面を指し，その原地形の如何にかかわらず「侵蝕さ れた地表面の頂面が略等高度に配置して，その切峯面は水平ないし緩傾斜を示し，かつ適度の広さを占め るもの」をいう. 岩石床や岩石段丘面はふくまれないものとする. 三野与吉 (1942) : 地形原論. 古今書 院, $240 \sim 244$.

2）たとえば，小林国夫（1962）：第四紀（上). 地団研地学双書，17，107〜194.

貝塚爽平他（1963）：木曾川・矢作川流域の地形発達。地理評，37，89 102.

同 (1963)：日本地形論 (上). 地団研地学双書, 19，57〜112.

水山高幸他（1967）：阪神とその周辺の地形. 地理評，40，585 600.

中野尊正（1967）：日本の地形. 築地書館, 76〜109.

中川久夫（1967）：丘陵地の成立に関する一考察. 佐々保雄教授還暦記念論文集，371３78.

3) Horberg L. C. (1952) : Interpretations of geomorphology, glacial geology and Pleistocene geology Jour. Geol. 60, 187 190. 
旧面図（第 1 図）に明瞭にあらわれているように， 高度 $300 \mathrm{~m} \sim 100 \mathrm{~m}$ の部分の定高性がとりわけ著し く，かつて陸前準平原と呼ばれたものの一部である. この丘陵は北上川の中流域と下流域をわかつ高ま りとなりここで北上川は北上山地の西縁に古生界 を刻んで，深い峡谷をなしている．この東西にのび る丘陵は西磐井郡にふくまれ，磐井丘陵と呼ばれる．

磐井丘陵は背面高度・地質・地質構造により，東 西に 2 分される. 磐井丘陵は盛岡一白河線 ${ }^{4}$ 上にあ り, 同丘陵の東西両部分を境するところには, ほぼ 南北にのび，東落ちの胆沢一油島撓 (拗) 曲線 あって,これは鮮新統下部を変位させ, 同中上部と 台地碟層の分布域を決定し, 地形発達にも重要な役 割をはたしている，磐井丘陵東部には，後述する中 山層と呼ばれる台地礫層が鮮新統上部をおおって, 丘陵頂に一致して広く分布しており, 一方, 磐井丘 陵西部は, 鮮新統下部・中新統を切る侵蝕面である.

従来，磐井丘陵の東部と西部は，それぞれ，1） 台地礫層の堆積面と第三紀層の削剥面よりなる一連 の平衡平原 (中川・寿円 $1959^{6)}$ ), 2) いずれも数段の

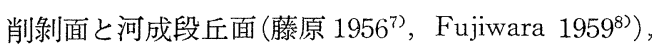

もしくは，3） いずれも一連の侵蝕面（田辺 $1950^{9}$ ， 中川 1961 10) ) と考えられている.これらの見解の 相異は磐井丘陵東部に分布する台地礫層の時代の解 勫に依るところが大きい。

磐井川以北，平泉西方の平泉丘陵は，磐井丘陵西 部よりやや高い部分があり，その一部には段丘礫層 が残存している．衣川をへだてて平泉丘陵の北方に は，胆沢川に沿う段丘群が広大な胆沢扇状地を形つ くっている.

磐井丘陵の南方の佐沼低地には，北上川の支流で ある迫川 3 川に沿って広い沖積低地・数段の段丘が 発達している.すくなくとも沖積低地に限ってみれ ば，海水準変動の直接およんだ海岸低地である．ま た洪積世末の海水準低下の影響は，峡谷を通じて， 北上川中流の一関〜水沢までおよんだと推定されて いる(阿子島 1968) ${ }^{11)}$ ，したがって，佐沼低地の段 丘群も，胆沢台地の段丘群も，一連に海水準変動の 影響を被ったことが予想される.

この地域の地質について，従来より多くの報告が なされている12) 27). 第 1 表にその概略を示した。

丘陵を構成するものは，中新世中期より鮮新世末

4）北村 信 (1963)：グリーンタフ地域における第三紀造構造運動。日本地質学会第 70 回総合討論資料, $43 \sim 63$.

5）松野（1967，脚注 27）によって総括されているように，従来いくつかの断層として個々の名称が与え られていたものが，早川ら（1954 a, b 脚注 20, 21）によって一連の断層として統一された. 藤原 (1954， 脚注 7）をはじめ地理的に断層としてとりあつかっているように明瞭な急斜面をともなっている. しか し, 小野寺 (1957, 脚注 22) はこれは撓曲であることを明らかにした。この一連の撓曲線の名称はいく つかある。その北方延長は胆沢台地の地下に潜り，台地面を変位させていることは村田（1939，脚注 52） をはじめ, 田辺(1950, 脚注 9), 若生 (1956, 脚注 53), Fujiwara (1959, 脚注 8), 藤原・中村 (1963, 脚注 45), 中川ら（1963 a, b，脚注 44）などに述べられている。沶そらく，洪積世末以降まで活動して いると推定された（阿子島 1968, 脚注 11).

6）中川久夫・寿円信吾 (1959）：花泉付近の谷系発達について．日本地理学会 1959 年度秋季学術大会研究 報告要旨, 15 .

7）藤原健蔵（1956）：北上河谷南部の洪積台地に関する 2 ・3 の知見. 第 19 回東北地理学会・日本地理学会 1956 年度秋季大会講演要旨, 12.

8) Fujiwara, K. (1959) : Geomorphological development of the Kitakami Valley Sci. Rep. Tohoku Univ. 7th Ser. (Geography) 8, 3 38.

9）田辺健一 (1950)：奥羽脊梁山地東麓の低位侵蝕面の $2 \cdot 3$ の問題（講演要旨）. 地理評， 23，132 133.

10）中川久夫（1961）: 本邦太平洋沿岸地方に打ける海水準静的変化と第四紀編年. 東北大学理学部地質学古 生物学教室研究邦文報告, 54, 1 61.

11）阿子島 功（1968）：北上川中下流域の河谷底の構造. 東北地理，20，206 214.

12）土田定次郎 - 島倉已三郎（1939）：北上川流域の新生代層一とくに夾要炭層の基底について. 東北帝大地 質学古生物学教室邦文報告, 32 . 


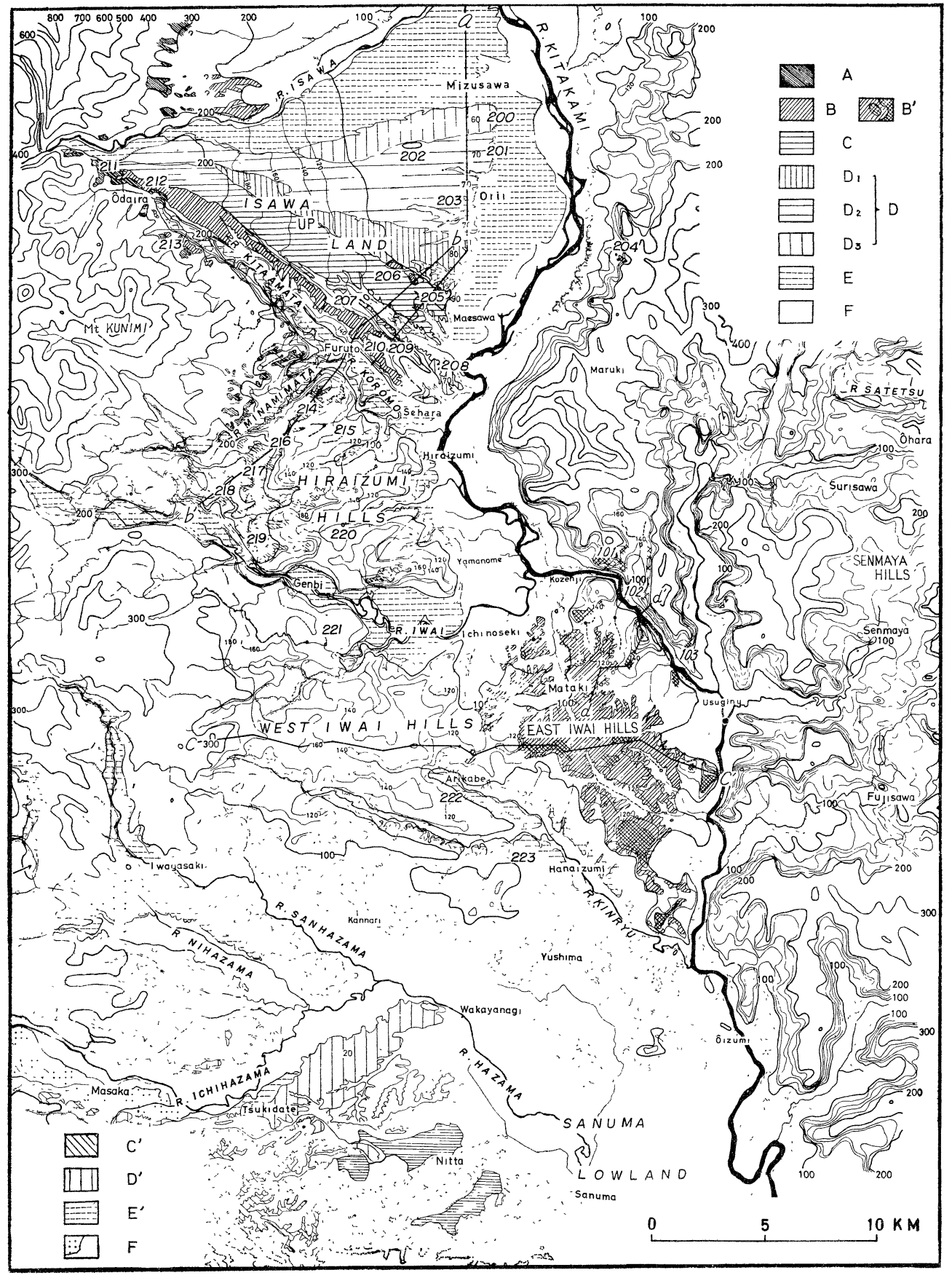

Fig. 1 The Iwai Hills and environs, the erosion surfaces and the terrace surfaces

The contour lines are restored by filling the valleys of the width of $500 \mathrm{~m}$ and traced at intervals of $100 \mathrm{~m}$ and partly $10 \mathrm{~m}$.

A ; The upper Ishuzaka surface and the Wayamä surface, perhaps dissected remnants of river terrace surfaces.

B; The Lower Ishuzaka surface, the higher terrace surface of Isawa Upland, and 
B'; The Suganodaira surface, the fill top terrace surface in Iwai Hills and the Nakayama Formation, the terrace deposits.

C; The Uenohara terrace surface of Isawa Upland.

$\mathrm{C}^{\prime}$; The Upper Kiyotaki terrace surface along the Hazama rivers.

D; The Isawa terraces; D-1; The Yokomichi terrace surface, D-2; The Horikiri terrace surface and D-3; The Fukuhara terrace surface.

$\mathrm{D}^{\prime}$; The Upper Tsukidate terrace surface along the Hazama rivers.

E; The Mizusawa terrace surface along the Isawa river and the Kitakami river, and the Hanaizumi terrace surface along the Kinryu river in Iwai Hills.

$E^{\prime}$; The Lower Tsukidate terrace surface along the Hazama rivers.

$\mathrm{F}$; Present river plain, and the Masaka terrace surface, the upper part of the alluvial plain.

K. P. o ….... The knickpoints in the valley floor profiles, rapids and falls, and the hanging valleys.

The cross profiles along the lines a, b, ….....are shown in Fig. 6.

にかけて, 現脊梁の地背斜化にともなって, この地 域が羽越地向斜東縁部の陸棚区から, 脊梁山地と北 上山地との間の山間沈降帯となったときの堆積物で ある.このうち, 油島層は, 北上川の河谷に沿って 広く連続して分布している鮮新世前期の海成層（西 方に分布している大平層は, 陸成の相当層) であっ て, 特徵的な貝化石相により仙台付近の竜の口層に 対比されている。これを扮抢う鮮新統中上部は, 亜 炭層をはさむ陸成層を主とし，北上川の谷に沿って 点々と分布している.これらは, 佐沼低地では瀨峯 層 (金沢層・築舘層)，磐井丘陵東部では金沢層・ 真㴰層, 胆沢台地では金沢層・折居層などと呼ばれ ており，台地礫層の直接の基盤岩となっている。こ れら夾亜炭層は, 仙台付近の八木山層・大年寺層な
どに相当するとされているが，この地域に限っても， 各地層相互の関係は必ずしも明らかではない，その ため後述するように，台地礫層の時代の解釈に大き なさまたげとなっている.これら若い鮮新統は，磐 井丘陵西部・平泉丘陵をとりまくように見出され， ここに段丘・低地がよく発達している.

\section{III 地形の記載}

\section{1. 磐井丘陵東部}

磐井丘陵東部には, 古生界からなる高度 $200 \mathrm{~m}$ 前 後のいくつかの孤立峯があり，これをのぞく大部分 の丘陵頂は, 高度 $140 \mathrm{~m}$ をこえず, 定高性が著しい. この高度 $140 \mathrm{~m}$ 以下の丘陵頂面は上下 2 分され, それぞれ营の平面および富沢面とよばれている28).

13) 山本正吾 (1941): 岩手県一関付近の地質. 東北大学理学部地質学古生物学教室卒論 (手記).

14）小原常二 (1947)：宮城県栗原郡築館町付近の地質. 同上.

15）木下 尚（1948）：岩手県水沢市近傍の地質について. 同上.

16）松野久也（1948）：岩手県一関付近の地質について。同上.

17）高橋 稠 - 森 和雄（1949）：宮城県築館炭田調查報告. 地質調查所月報，3，174 190.

18）高橋英雄 (1950)：細倉鉱山周辺の地質構造. 東北大学理学部岩石学鉱床学教室卒論 (手記).

19）小野寺信吾 (1951)：一関付近の新生界. 東北大学科学教育研究室修論 (手記).

20）早川典久他（1954a）：岩手県地質図・同説明書. 岩手県.

21）同 (1954b): 岩手県北上山地面縁より脊梁山地に亘る地域の新第三系の地質 (4). 東北鉱山， 1, $1 \sim 97$.

22）小野寺信吾（1957）：岩手県一関市で発見された Desmostylus とその産地付近の地質. 地質学雑誌，63, $238 \sim 253$.

23）庄司力偉（1958）：宮城県北西部亜炭田地域の地質一蘚新統に発達する堆積輪廻の生成に関する研究. 東 北鉱山, $5,1 \sim 25$.

24）北村 信 -小貫義男（1963）：宮城県地質図 $(1: 200,000)$. 内外地図.

25）木野義人（1963）：表層地質 $1: 50,000$ 「水沢」土地分類図. 経済企画庁国土調查.

26）小貫義男 (1966)：一関東南方丘陵地の地質とその重要性. 地学研究, $17,176 \sim 182$.

27）松野久也（1967）：1:50,000 地質図「築館」. 地質調查所地域地質研究報告, 69.

28）前掲 8）によれば，菅の平面は台地磁層（中山層）の堆積段丘面，富沢面はこれを切る侵蝕段丘面。 


\begin{tabular}{|c|c|c|c|c|c|c|c|c|c|c|c|}
\hline \multicolumn{2}{|c|}{ 住 } & \multicolumn{2}{|c|}{ 沼 低 } & \multicolumn{2}{|c|}{ 磐 } & 井 & \multicolumn{2}{|c|}{ E 陵 } & \multicolumn{2}{|c|}{ 胆沢台地 } & \multirow[t]{2}{*}{ 地域 / t+ } \\
\hline $\begin{array}{c}\text { 森 他 } \\
1949 \\
\end{array}$ & $\begin{array}{c}\text { 北村他 } \\
1963 \\
\end{array}$ & $\begin{array}{c}\text { 松 野 } \\
1967 \\
\end{array}$ & $\begin{array}{c}\text { 阿子鼻 } \\
1966 \\
\end{array}$ & \multicolumn{2}{|c|}{$\begin{array}{c}\text { 阿 } \\
1968\end{array}$} & $\begin{array}{r}\text { 中 } 111 \\
1963 \\
\end{array}$ & \begin{tabular}{|l} 
小野寺1957 \\
早川1554 1954 \\
松野1948 \\
\end{tabular} & $\begin{array}{c}\text { 土田他 } \\
1939 \\
\end{array}$ & \multicolumn{2}{|c|}{$\begin{array}{c}\text { 木 } 1963 \\
\end{array}$} & \\
\hline \multirow{2}{*}{$\begin{array}{l}\text { 築 舘 } \\
\text { 夾亚炭層 }\end{array}$} & 清瀧層 & & 高位清瀧砂碂層 & \multirow{6}{*}{ 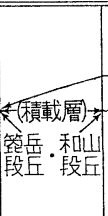 } & & & & & \multirow[t]{3}{*}{ (胆沢台地) } & \multirow[t]{3}{*}{ (北上)涷岸) } & \multirow{3}{*}{ 洪積世 } \\
\hline & 新 田 & 梅方沢 & 新田凝灰岩・ & & & 積載層(次) & & & & & \\
\hline \multirow{3}{*}{$\frac{上 \text { 部 }}{\text { (鮮新統) }}$} & 凝灰岩 & 凝灰岩 & 北川石英安山岩 & & 中山層 & 㴰沢層 & 中山層 & 弥栄層 & & & \\
\hline & & 高清水曯 & & & \multirow{4}{*}{$\begin{array}{c}\text { 真瀧層 } \\
\text { 略 }\end{array}$} & \multirow[t]{2}{*}{ (真㴰層) } & \multirow{2}{*}{$\begin{array}{l}\text { 真 瀧 } \\
\text { 夾西炭層 }\end{array}$} & 真 澈 & \multirow[t]{2}{*}{ 折居層 } & \multirow[t]{2}{*}{ 羽黒層 } & \multirow{5}{*}{ 鮮新世 } \\
\hline & 瀨峯層 & 筑舘曒 & 瀨峯層（踏㖬） & & & & & 夾垔炭層 & & & \\
\hline 同下部 & & 金沢層 & & & & 略 & 金沢層 & 金沢層 & 金沢畨 & 金沢屓 & \\
\hline \multirow{4}{*}{ 玉里介層 } & 竜の口層 & 竜の口層. & 玉里介層（”） & \multirow{4}{*}{\multicolumn{3}{|c|}{ 整合 }} & 油島尊 & 油島介層 & 油島層·大 & & \\
\hline & & 軍烊層 & （竜の口層相当層） & & & & 有賀層 & 有壁虚 & 平層·有損層 & & \\
\hline & & 下黒沢層 & & & & & 厳美層 & & 撖美層 & & \multirow[b]{2}{*}{ 中新世 } \\
\hline & & 石越安山岩 & & & & & 下黒沢層 & & 下黒沢層 & 稻瀨層 & \\
\hline
\end{tabular}

(段互堆積物は一部のみ)

また丘陵の開析谷中に低い段丘面がある.

\section{a）菅の平面と中山層}

中山層とよばれる台地砂層は，高度のよくそろっ た丘陵頂面に一致して分布しているので, 鮮新統真

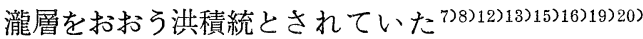
211222．しかし，中川 $(1961)^{103}$ は，これを瀧沢層と 呼び，真瀧層とは整合的なところがあり，かつ真瀧 層以下の地層の示す地質構造に参加しているので, 鮮新統真瀧層とは一連の，下部更新統であるとした． したがって，この丘陵背面である菅の平面は，「台 地礫層の堆積面」であるのか，「鮮新統に一連な下 部更新統の砂砂層までを切って生じた侵蝕面」であ るのか，2つの解釈が生ずることになる.

菅の平面は，高度 $140 \sim 130 \mathrm{~m}$ の丘陵頂を連㸚た 背面である．丘陵頂に，いわゆる新期の台地面にみ られるような平坦面は認められないが，山稜は幅が 広く，なだらかであり，高度がよくそろっている。 (第7図一A)。したがって，富沢面と地形的不連続 はないが，復旧面と後述する中山層上部の分布域を 重㸚合わせて第 1 図に示した。菅の平面は，これら を連㱛た背面である。菅の平面は，南東に高く，北
西に低い299.

以下述べる事項により，中山層は現在の状況にほ ぼ近い，北上川の前身のもたらした河床・氾濫原堆 積物であり，菅の平面は中山層の堆積面を示すこと が推定される.なお,古生界の粘板岩・硬質砂岩・薄 衣磁岩を切る平坦な, 幅広い山稜があり ${ }^{300}$, その高度 は中山層の上限高度よりやや大きいが，比高は最大 20mを越えない，これは中山層堆積時に低い、河間地 となっていた侵蝕面とみることができる。すなわち

1. 菅の平面の広がりは，中山層の分布域とほと んど一致している.

2. 菅の平面は，中山層の分布しない東西両側の 侵蝕面よりは，高度が一段と低く，高度がよくそ ろっている。

3. 中山層は河成相を示す.

4. 中山層をおおう地層は認められておらず31), その最上部は flood plain sand・ silt にあたる.

5. 中山層は sheet type を示し，その広がりは 北上川沿いの谷底面の広がりに等しい。

6. 中山層の基底は谷状をなし，真瀧層との関係 はおそらく平行不整合である。

29) 86 で高度 $140 \mathrm{~m}, 3$ で高度 $100 \mathrm{~m}$.

30） 16，20，30，55，77，101，102，103 など（第 6 図-d）.

31）後述する佐沼低地の低い丘陵の基盤岩の一部をなす高清水層（松野 1967，前掲 27）とは必ずしも対比 されない。 
7. 中山層の古水流は，ほぼ南へむかうものであ ったと推定される.

8. 菅の平面の傾きは，侵蝕にあずかった開析谷 のそれぞれの排水点の高度の差が反映されている のではなく，堆積面にほぼ近いものが地盤運動に よって傾いたとして説明できる.

以下, 中山層について述べる.

中山層の層相 中山層は砂礫・砂・粘土よりなり， 厚さ最大 $40 \mathrm{~m}$, 広がり $16 \mathrm{~km}(\mathrm{NW}-\mathrm{SE}) \times 8 \mathrm{~km}(\mathrm{NE}-$ -SW) の sheet 状の地層である。ほぼ全域にわたっ て上中下部に 3 分できる. (第 $2 \cdot 3$ 図).

下部層は，厚さ $10 \mathrm{~m}$ の砂碟層である，その礫は 径 1 $20 \mathrm{~cm}$ であり，比較的水磨されており，一般 に上方に小さくなる ${ }^{32)}$. 礫種は，古生界由来のもの が大部分を占め，44でも，おそらく新生界由来とみ られる安山岩質の礫は数個が認められたにすぎな ( ${ }^{33)}$. 古生界の薄衣碟岩などに由来するとみられる 礫は，もともと円磨がすすんでおり，硬く，風化を まぬがれている。しかし，これ以外の礫は風化がす すみ，ハンマーの刃で切れる。 下部層には砂・粘土 のレンズがはさまれ，偽層の著しい発達や，礫の明 瞭な imbrication がみられる.

中部は砂・粘土層よりなる，粘土層は白色，とき に赤色を呈し，草炭をはさむことがある，2 では多 量の浮石粒をふくんでいる。

上部の砂層は, 主に中粒砂よりなり，斜行葉理が 著しい，その最上部にあたる 86 では, 最大径 $10 \mathrm{~cm}$ の礫もふくまれている. 上部層は概して, 河川の洪
水時にもたらされる細粒の氾濫原堆積物にあたると みられる34).なお，中山層の碟層や各部層の内に著 しい削り面などは認めることができない．

中山層と基盤岩との関係 各露頭に掞いて，中山 層直下の基盤岩の上面に，風化帯や大きな凹凹はな い35). しかも，基盤岩である真瀧層に鍵層になるも のを欠くため，各層準を広く追跡できず，また近隣 地域に分布する上部鮮新統の各層とも対比はできて いないため，中山層の基底の示す不整合の大きさは, とらえられない。しかし，後述するように中山層の 基底が谷状を呈し，中山層直下の真瀧層とされる地 層の岩相が東西に異なること，くわえて，中山層の 分布する地形面が段丘面であるとするときには，そ の高度と位置から，真瀧層の上位の地層を削り去っ た，真瀧層と中山層の間の不整合の示す時間間隔は 大きいことになる．

中山層の基底の地形 各露頭の範囲内では，中山 層の基底に著しい削り面のみられることは少ないの で，約 $1 \mathrm{~km}$ 間隔の測点によって求められた基底面 （第 4 図）は，そのまま中山層の基底の地形を示す ことになる。

中山峠 69 から真瀧 11 や下瀧沢 1 にかけて, 概略 北西一南東にのびる谷をなし，基底はこの谷に沿っ て，北へいくほど低く，海抜高度 $80 \mathrm{~m}$ まで下って いる.この谷の南西側では, 地層の連続によって中 山層であることが確実な 36 で高度 $110 \mathrm{~m}, 110$ で $130 \mathrm{~m}^{36)} ， 32$ では高度 $120 \mathrm{~m}$ で細粒の砂礫層がある。 この谷の北東側では，基底の高度が比較的急勾配で

32）この変化は，植立趾付近 65-66-68, 中山峠付近 69, 大峠付近 73-74にかけてよくみられる. また 13 で は，基底部に径 $1 \mathrm{~m}$ の古生界由来の岩塊が含まれているが，すぐ上方では，細粒の礫になっている。

33）前掲 13），8）などは，東方では古生界由来の碟が多く，西方では新生界由来の礫が多くなると述べて いる.なお，磐井丘陵西部・平泉丘陵の中新統・鮮新統の礫岩中にも，粘板岩など古生界由来の礫が相当 見出される.

34）現在の北上川の中流における河床䃯の大きさは，中山層下部のそれにほぼ等しく，下流の佐沼低地では， ほとんど砂となっている.

35）ただし，前掲 27）は，老松村宿沢 89 付近において，中山層が真瀧層の浮石質凝灰岩を，水平距離 $30 \mathrm{~m}$ の間に，12mほど削り込んでいる露頭を示し，大局的には平行不整合であるとしている.

36）撓曲線に近いので，撓曲構造に参加する下位の地層の疑いもあるが，111に亜炭をはさむ真瀧層が高度 $120 \mathrm{~m}$ ま゙露われているので，おそらく中山層であると考えられる。 
増加し，古生界を直接打打って いる.

また59，60では，古生界の 粘板岩と真瀧層の砂岩を一様に 切ったと推定され，北方の 56 では，古生界の露われた，やや 小高い部分があって，ここでは 中山層はあっても非常に薄かっ たとみられる(第3図)，以上 のように，中山層の基底の低い ところは，第三系の分布してい るところである。したがって， 中山層は，第三系の撓曲構造を 生ビた時一連の構造運動をうけ つつ形成された谷を埋積したも のであり，その過程で東方の古 生界の谷壁斜面を埋め，ときに 側刻を行ないつつ堆積したもの と解される.

\section{中山層の古水流 中山層下部} の砂碟層の gravel fabric を 13 地点で測定した ${ }^{37)}$. うち 6 例は非常に明瞭な orientation pattern が得 られた (第 5 図).

測定地点間隔は $0.5 \sim 2 \mathrm{~km}$ であり，測定に適する 露頭は限られているため, 統計的に areal level で古 水系を論ずることは出来ない，しかし，中山層の基 底の示す谷の軸にほぼ沿うょうにみえ, 露頭での他 の堆積構造（偽層・斜交葉理）を考え合わせると古 水流は北から南にむかったものが多いと推察される.

地盤運動 中山層の堆積面を示す菅の平面は，北 西に低く，中山層の基底も北西に低い，中山層堆積

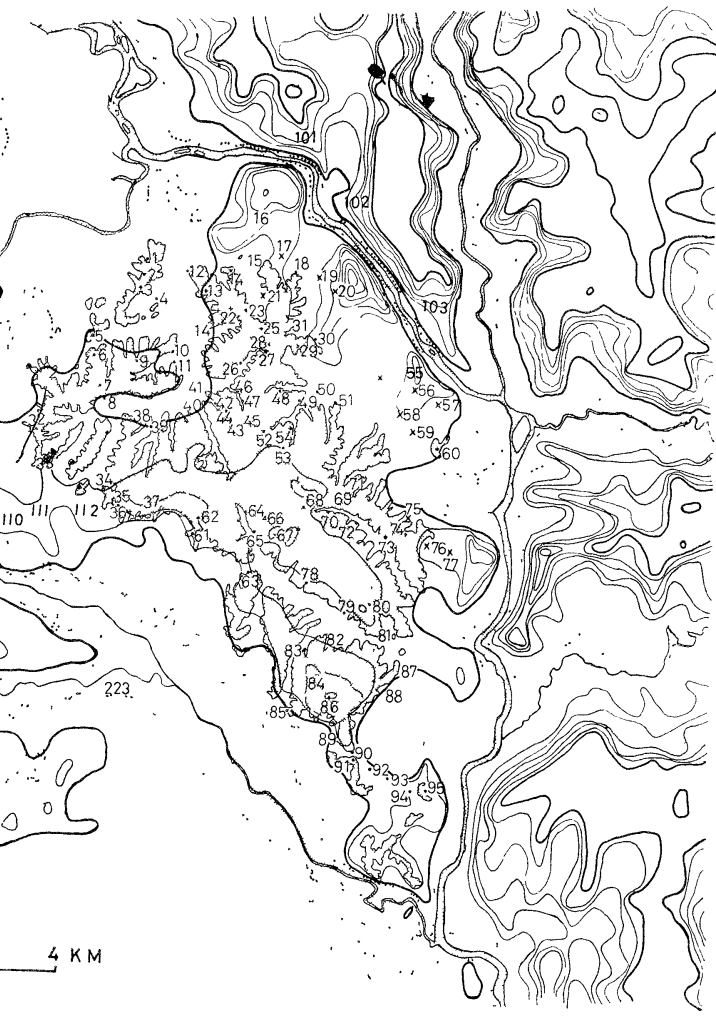

Fig. 2 Location map of the outcrops

時の古水流は，おそらく南へむかったものと推定さ れた。したがって，菅の平面は中山層堆積後，北西 方へ傾動したことになる ${ }^{38)}$. その運動は，第三系の 撓曲構造に一致し，松野 $\left(1948^{16)}\right)$ が想定した「中 山地塊の東西方向の分水界付近を不動軸とする hinge fault」に似た様式であり，その不動軸に相当 するところで，胆沢一油島撓曲線に沿う撓曲構造の 傾きが最も小さく ${ }^{39)}$ ，丘陵頂が東西両部いずれも最 も高く，分水界をなしている(第 4 図)。この撓曲 運動は中山層の堆積域を決定しているのみならず, 菅の平面の陸化後の水系の発達（真瀧付近など）を

37） Schlee（1957）の提案した “apparent dip direction measurement method”にほぼ準じた. fabric が明瞭 な場合には 60 80 個の測定で明瞭な orientation pattern が得られた。測定個数・露頭の選択・測点間隔 などの吟味は別に報告したい. Schlee, J. (1957)：Fluvial gravel fabric Jour. Sedi. Petrol., 27, 162 176.

38）この傾動運動は，前掲 6)，7），8），16）も述べている.

39）前掲 27）の第 7 図によった。

40）前揭 26）が新たに提案した孤禅寺一日形構造線に一致している。この構造線は古生界の深度からして 異なるというものであるが，真瀧層堆積後の運動については不明と述べていた。 

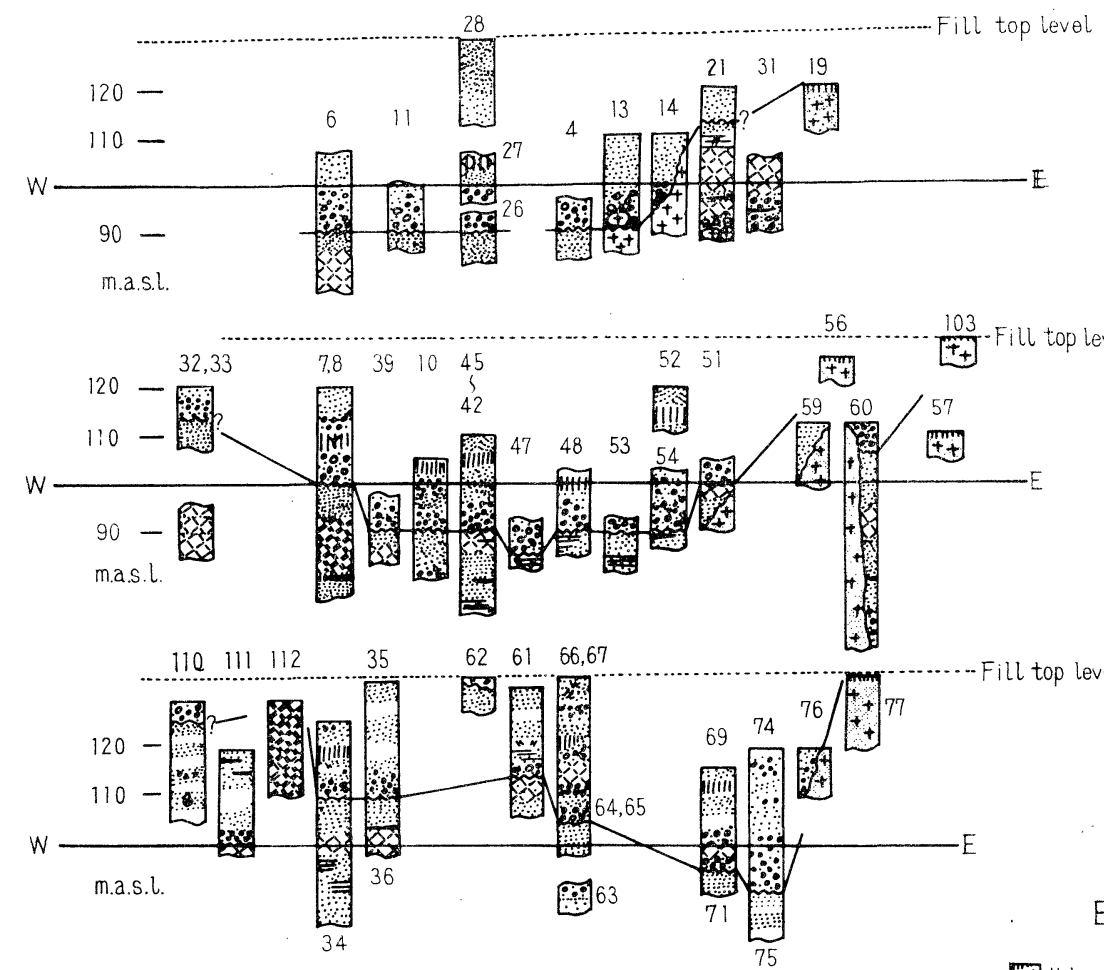

\section{EXPLANATION}
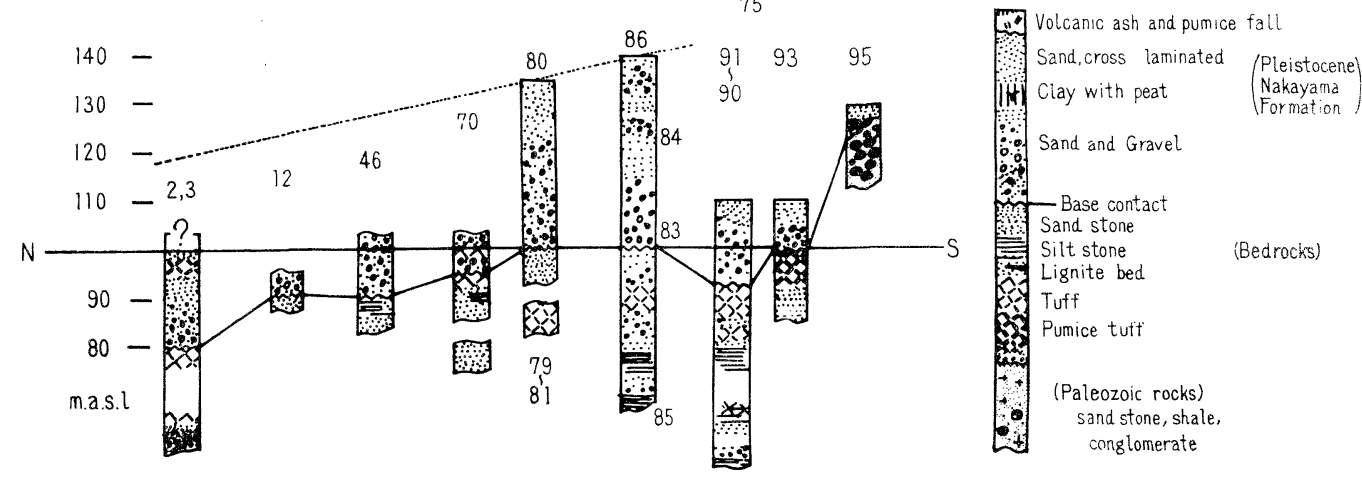

Fig. 3 Outcrop columns of the Nakayama Formation

も支配していることが明らかである ${ }^{40) .}$

b) 富沢面

菅の平面を切る侵蝕面で，なだらかにつづく幅の 広い尾根であり, 磐井丘陵東部の主要な地形要素を なす.この地形面の成因を直接指示する堆積物はな く ${ }^{41}$, 中山層の各層準・真瀧層・古生界が露われて いる. またこの地形面が河川の側刻によって生じた
「菅の平面を切る侵蝕段丘面」とは考えられず，そ の根拠となった，菅の平面との地形的不連続を示す 中山峠 69 付近の直線状の急斜面は，いくつかの開 析谷の谷頭が一線に並ぶような位置にあって生じた と解される.この地形面は, いたるところの開析谷 の谷頭付近に，特徵的な浅く広、谷を伴なっている. この浅く広い谷は, 開析谷底とは連続せず, 谷壁・

41）前揭 8) に扔いて, その標式地とされた富沢 59，60 では, 中山層はほとんど削り去られて真瀧層の砂岩 や古生界の粘板岩が露われている。 
谷床に傾斜の変換点をもって いる. しかし，この種の谷 ${ }^{42}$ は，かつての平坦面に起源す る小起伏の分水界付近には通 常にみられ，それぞれが過去 の特定の基準面を反映してい るとはかぎらない。

東方にむから支谷では, 谷 床に古生界が露われ，ここで 遷急点が保持され，その上流 側にはこの浅く広い谷がよく 発達し, 小起伏の地形が展開 している（第7図一A）.

c）谷中の段丘と谷底面 佐沼低地側に注ぐ金流川沿 いに，花泉段丘 ${ }^{43)}$ と呼ばれる 低い谷底段丘があり，これは 前沢火山灰 ${ }^{10344}$ に打打われる ことはない．花泉段丘背後の 小規模な段丘面 223 や斜面 222 は前沢火山灰におおわれ ている。一関側に向う支谷中 にも低い段丘面が認められる. 谷底面は北上川主流にすで に平衡しているものと，遷急 点によってへだてられている ものがあるが，同一基準面に

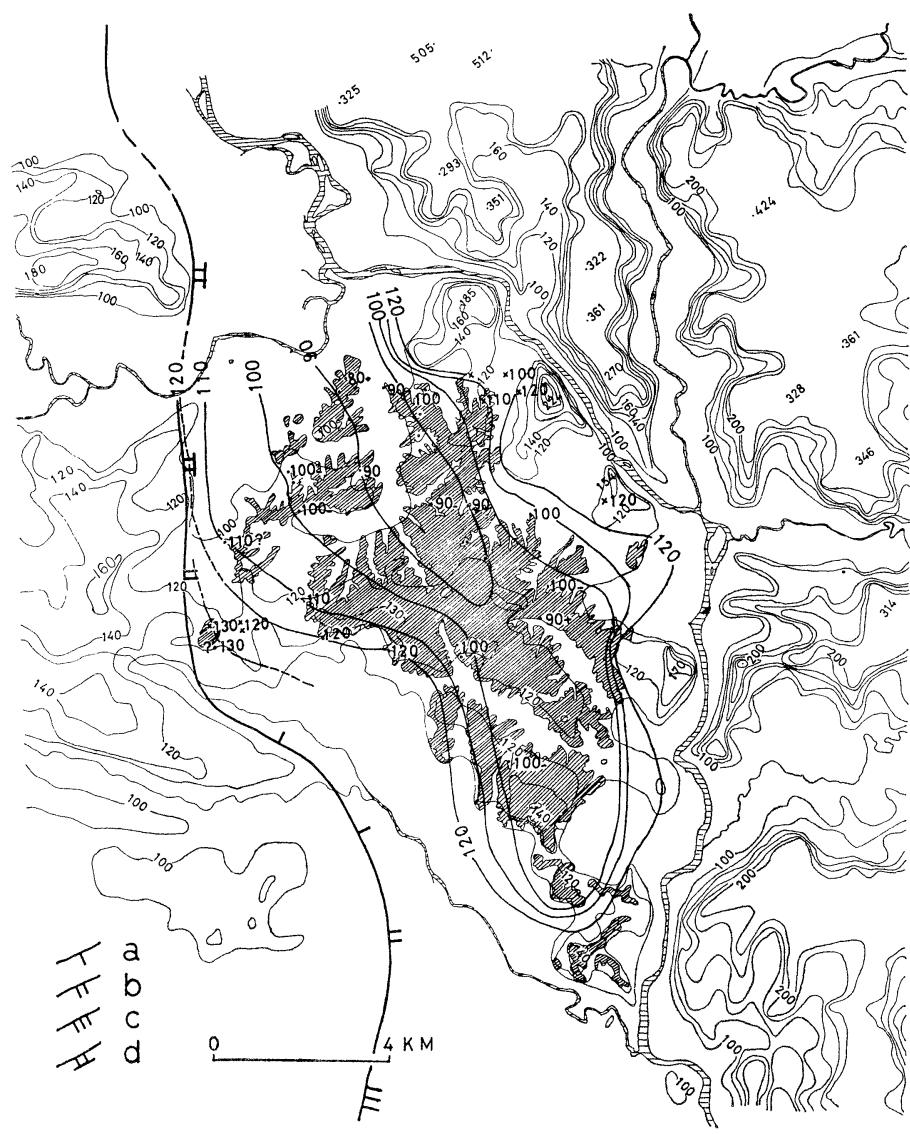

Fig. 4 Contour map of the base of the Nakayama Formation

Note the gradient to the north same as the Fill-top surface, and the coincidence of the form of the base with the drainage pattern development.

Dip of the bedrocks along the Isawa-Yushima line of flexure after Matsuno (1967);

a $; 1^{\circ}-19^{\circ} \quad$ b; $20^{\circ}-45^{\circ} \quad$ c $; 46^{\circ}-70^{\circ} \quad$ d $; 71^{\circ}-89^{\circ}$

The divide of Iwai Hills coincides with the part where the dip of the bedrocks along the line of flexure is the smallest.

42）中村（1963・他）の「高位侵蝕谷」に相当する.

中村嘉男（1963）：篦岳丘陵における高位侵蝕谷と地形発達。東北地理，15，22２8.

43) Kanto Loam Research Group (1961) : On the geological age of the Hanaizumi Bed, manmalian deposits of the glacial age, North-east Japan. 地球科学, 53, 28 31.

関東ローム研究グループ・信州ローム研究グループ（1962）：花泉層の堆積環境とその地質時代につい て(1)(2). 地球科学, $62,1 \sim 10,63,10 \sim 18$.

44）火山灰の名称は中川（1961），中川ら（1963a，b）に従った．胆沢台地に分布する最上位の火山灰層は， 黒沢尻火山灰と呼ばれ，褐色火山灰層と黄褐色浮石層よりなる. 黒沢尻火山灰層の下位の前沢火山灰層は, 火山灰層と浮石層の数枚の互層よりなるとされている. 222 には，火山灰・浮石層が 2 枚あるので，少く とも前沢火山灰層まであることになる。

中川久夫ら（1963 a）：北上川上流沿岸の第四系および地形(1). 地質学雑誌，69，163〜171.

同 (1963 b)：北上川中流沿岸の第四系および地形(2). 同上，69，215 227. 
注ぐ水系内の支谷でも, それぞれの長 さによって互に切り合っている.

\section{2. 磐井丘陵西部と平泉丘陵}

この地域の丘陵の背面は非常によく そろって抢り，5万分 1 「関」図幅 の西側半分にわたって, 高度 $250 \mathrm{~m}$ を 越えるところはほとんどない，また， 丘陵背面は一般に東にむかって高度を 減ずるが，第三系の複撓曲構造に一致 して ${ }^{8)}$, 波状をなして高度を変化させ る(第 1 図・第 6 図一C).

最も高い和山面 (高度 $260 \sim 200 \mathrm{~m}$ )

は，磐井川・南股川の段丘面であり，

より東方に分布する丘陵頂面は, これ よりも低い侵蝕面である。平泉丘陵を 刻む開析谷の谷底面は，懸谷状をなす ものがあり ${ }^{45)}$, 対岸の胆沢台地の各段 丘面と関連づけられる.

a) 和山段丘

南股川沿いに, 高度 $200 \mathrm{~m}$ 以上の定 高性がよく，幅のやや広い山棱が連続 しており, 磐井川との分水界である和 山付近 218 では, 高度 $260 \mathrm{~m}$ の, ゆる やかな波状地をなす広い面をなしてい る.これらの一部に段丘堆積物とみら れる砂礫層が残っている. 段丘堆積物 の基盤岩は鮮新統油島層相当層 ${ }^{46)}$ であ

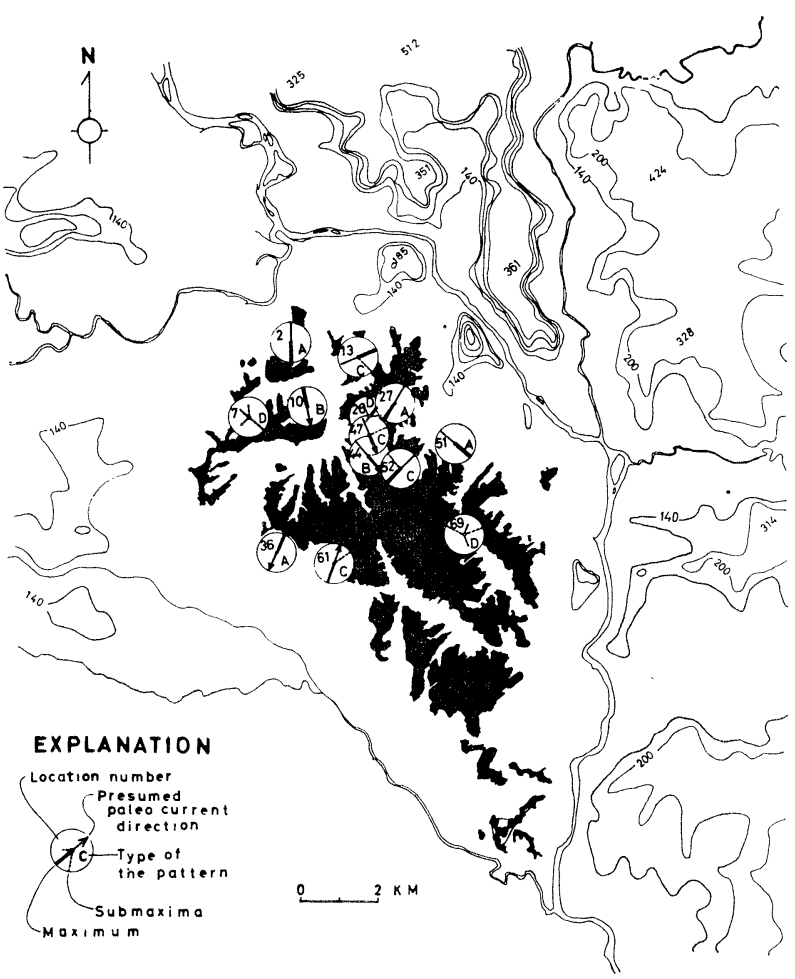

Fig. 5 The paleo-current of the basal gravels of the Nakayama Formation

Restored contour of the height of $140 \mathrm{~m}$ a.s. l. shows the fill-top level of the Nakayama Formation.

The type of the pattern of the orientation rose of the gravel fabric, measured mainly after Schlee's "apparent dip direction measurement method";

A; Concentrated form prefered in one direction,

B; Elongated form prefered but in opposit two directions,

$\mathrm{C}$; Relatively concentrated form in one direction having submaxima, and D; Irregular form

With the help of other sedimentary structure, A, B and $C$ give the paleo-current flow directions, wholly it prefers southward.
り，段丘砂礫層と基盤岩中の砂礫層とは区別がつき

難いが47)，前者の基底は起伏に富むと推定された

(第6 図一b). この段丘堆積物に整合に重なる火山 灰層はなく，ゆるやかな波状の起伏に沿って，新期
の火山灰・浮石層が堆積している(第 6 図一b).

この平坦面からなだらかに連なる，定高性のよい 山稜が広く分布するが48)，その分布形により磐井 川・南股川沿いの和山段丘面に起源するものとみら

45）藤原健蔵・中村嘉男（1963）：地形 1：50,000「水沢」土地分類図. 経済企画庁国土調査.

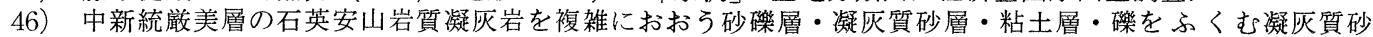
層など.

47）䃯径・風化の程度などに差はなく，両者の位置により区別される。段丘堆積物は，217，218，219にあ って高度を異にし，219 では基盤岩の砂岩層に凹凸面をもって接している.

48）前掲 25）において平泉段丘とされたものにあたる. 同段丘堆積物とされたものと油島層相当層の基底 砂礫層（216にて高度 $200 \mathrm{~m} ）$ との区別がつき難い。ただし, 段丘堆積物とされたものの下位におそらく 油島層があるとされている。 


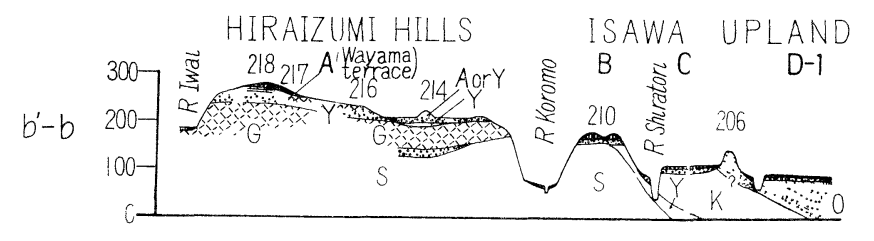

$N$ : Plesstccene Nakayama Formation O.M:Pliocere Oru and Matakı Formation $K$ : Pliocen? Kazawa Formation

Y.A: Pliocere Yushima and Arı́a Formation

$G$ : Mioceni Genbl Formation

S. Miocen Simokurosawa Fermaııon

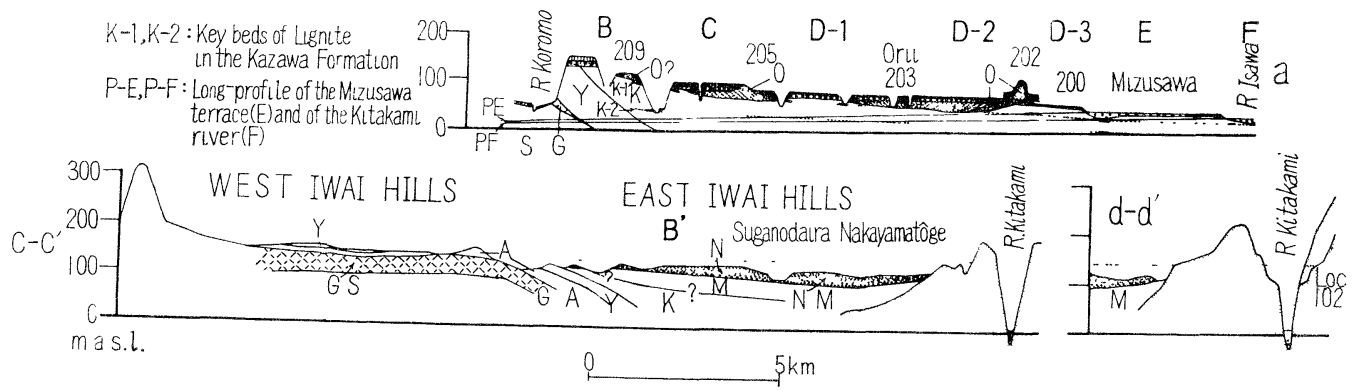

Fig. 6 Schematic cross sections along the lines a, b, c and $d$ in Fig. 1

Geology are mainly after Onodera (1957) and Kino (1963). Key letters of the terraces are same as in Fig. 1.

れる. 南股川沿いのものは, 後述する衣川の対岸の 胆沢台地の一首坂段丘低位面よりは若干高い，

b) 低位の丘陵面と谷底面

上述の丘陵頂面よりは低いが，定高性の良い山棱 があり $(215 ， 221)$ ここれらはすべて厳美層の浮石 質凝灰岩に構成されている.ここでは開析谷の谷床 に厳美層の熔結凝灰岩が露われ，大きな遷急点が形 成され，懸谷となっている，厳美層の凝灰岩の厚さ は数十mにすぎず,これに構成される山稜と懸谷の 谷床までの間に小起伏地が展開している（第 7 図一 B).

\section{3. 胆沢台地とその周辺}

胆沢台地に関する地形学的研究は数多〈9>45) 49>
${ }^{54)}$, とりわけ最近では, Fujiwara $(1959)^{8)}$ が地盤運 動に注目しつつ地形発達史的観点より, 中川ら $(1963 \mathrm{a}, \mathrm{b})^{44)}$ が北上川上中流の広域にわたる火山灰 編年に基づいてこれをとらえ，木野 $(1963)^{25)}$ は岩 相図をもって第三系の地質構造を明らかにした．磐 井丘陵との関連において以下の 3 点を付け加えたい．

a) 従来の一首坂段丘面は 2 分される. 扇頂付近 において，下流方から比較的連続のよい平坦面 ${ }^{55)}$ り一段と高い面が認められる。この関係は北股川右 岸 213 でも同様に認められる。したがって，それぞ れを一首坂段丘高位面・同低位面と呼ぶが，高位面 の内容はとらえられない，な打北上川東岸 204 に高 度 $160 \mathrm{~m}$ の段丘があり ${ }^{56)}$ ，同低位面と対比される.

49）渡辺万次郎（1920）：北上縦谷中流部について。地球，6，515 519.

50）東木竜七（1929）：河岸段丘の非対称配置とその成因(4). 地理評，5，673 699.

51）田山利三郎・土田定次郎 (1933) : 北上山地の地形学的研究 その 1 河岸段丘 B. 北上川及び馬淵川 の河岸段丘. 斎藤報恩会学術報告 22 .

52) 村田貞蔵 (1939)：胆沢扇状地の形態学的研究. 地理評, 15, 134 147.

53）若生達夫（1956）：北上川中流域の表層地質による地形面区分. 東北地理，9，47 52.

54）榑松静江 (1964)：形成機構からみた胆沢扇状地の地形 (講演要旨). 地理評，37，674〜675.

55）一首坂段丘低位面の構成層は最大径 $1 \mathrm{~m}$ 以上の岩塊をふくむ厚さ十数 $\mathrm{m}$ の砂砂層であり，212 では大平 層を打抽ている．な打東にむかって下黒沢層・金沢層を順に打抢うとされている．またこの面はつねに

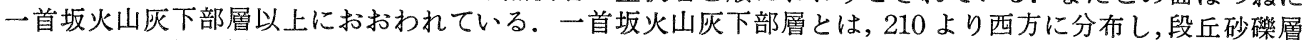
直上にうすい粘土層をへだてて，ほぼ水平に重なっている厚さ $1 \sim 2 \mathrm{~m}$ の赤褐色を呈する特街的な浮石層。

56）金沢層を打打う厚さ $20 \mathrm{~m}$ の砂礫層よりなる，構成層の中部に砂層をはさみ，層相は概して中山層のそれ に似て打り，北上川本流沿いの河床堆積物とみられる。灿灰層はない。 
磐井丘陵東部の菅の

平面は，胆沢台地の一 首坂段丘低位面と対比 できる、すなわち，菅 の平面は変位している が，前述のように，そ の不動軸に相当すると ころでの中山層の堆積 上面高度は $140 \mathrm{~m}$ ，基 底の最深部は $100 \mathrm{~m}$ で ある, 一方, 胆沢台地 の上野原面は，205 に おける上面高度が 100 $\mathrm{m}$, 礫層の基底が $90 \mathrm{~m}$ であり，しかも礫の fabric より, ここでは まだ北上川本流には合 流していないので，本流にむかって高度はより低く なる、また，これより一段高い一首坂段丘低位面は 東端（210の東方）で高度 $150 \mathrm{~m}$ であり，しかも， 菅の平面と磐井丘陵西部の丘陵背面との関係と等し く，一首坂段丘低位面は，平泉丘陵の和山段丘面に 連なる山稜面より高度が低い。

b）各段丘堆積物の基盤岩は，笅美層・大平層 (油島層)・金沢層・折居層であり，北にかたむいて 順に重なっている.このうち最上位の折居層は, 主 に中山層のそれに似た層相を示す砂磁層よりなる57) が，その上部はち密な砂岩層であること、またその 高度により，中山層とは対比されない。 rejuvenation. roded out.

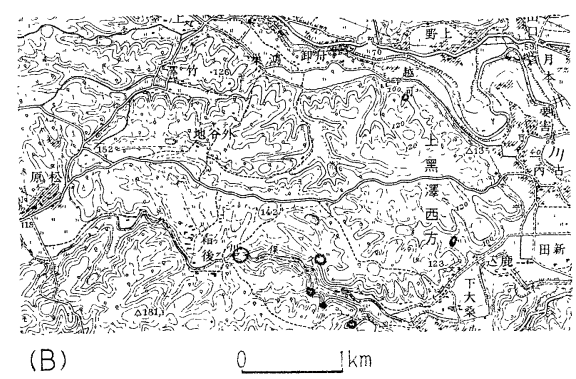

(B)

Fig. 7 Ridge and ravine landscape

A. Undulating surface originated from the Suganodaira terrace surface $(130-140 \mathrm{~m}$ a. s. 1.) in East Iwai Hills. $\times$; almost original level of the Suganodaira terrace surface $\times \times$; low interfluves when the Nakayama Formation deposited Knickpoints with the Paleozoic hard rocks exposure protect the undulating erosion surface (Tomisawa surface) from

B. Undulating surface controlled by lithology of the pumice tuff bed and the welded tuff bed of the Miocene Genbi Formation at 221 in West Iwai Hills. The undulating surface revealed itself after the terrace deposits of the highest terrace such as the Wayama terrace in Hiraizumi Hills and the underlying bedrock Yushima Formation were

The composing rocks of flat ridges are mainly the pumice tuff bed and partly the overlying sedimentary rocks, the Yushima Formation. $O$; knickpoints outcropping the welded tuff.

c) 各段丘面は，北へむかって階段状に配列する が，各段丘面に対応する小規模な段丘面が，207な ど高位の台地面を刻む支谷中に，また 208 など北上 川に沿って，高位の面をとりかこむように分布す る ${ }^{58)}$. すなわち，胆沢川の旧河床面の配置は第三系 の地質構造 ${ }^{599} に$ 支配されているけれども，これらを 段丘化した北上川本流沿いの基準面は間歇的に低下 したものと推定される.

\section{4. 佐沼低地}

鮮新統の堆積盆でもある佐沼低地には，段丘がよ く発達し，第 2 表のようにわ壮られる ${ }^{60)}$. 以下補足 すると、

57） 203 付近では，最大碟径 $10 \mathrm{~cm}$ 程度の全体に細粒の分粓のよい，水磨のすすんだ亜円礫を主とし，著しい 偽層の発達をみる厚さ $10 \mathrm{~m}$ の砂礫層であり,これを掞打う段丘堆積物とは明らかに異なる，功て，前 掲 15)の藤里層などとともに，中山層と一連とされていた。なお，同様の層相を示す砂礫層は真瀧層の一 部 ( 2 付近) にもふくまれる.

58）くわえて，北上川の対岸，水沢の北東方，岩谷堂付近（第 1 図の北東端・図幅外）の段丘面群も胆沢台 地の上野原面以下の各段丘面と非常によい対応を示している.

59）鮮新統の各層は北へかたむいて順に重なっている.折居層のみは第 6 図-a のような分布を示し，ここに 段丘面の広がりが大きく，その両側には高位の面の残存とみられる残丘（202は前揭 25）による，およ び206) の基盤岩となっている.

60）阿子島 功（1966）：迫川沿岸の地形. 東北地理，18，123〜 132。

次いで，前揭 27）により報告されたが，一致をみない点がある。以下，新たな資料と相異点について 述べる. 
a）佐沼低地の鮮新統の堆積盆の南を限る, 主に 中新統の高まりである笓岳丘陵 (高度 $200 \mathrm{~m}$ ) の頂 部をおおう風化した砂碟層 ${ }^{61} は$ は, 段丘堆積物とみら れる。

b）高位清瀧砂礫層堆積面としたものは，地域の 西方の鳴子付近より広く分布している北川石英安山 岩と一連とされる新田浮石流凝死岩を切っておおう, 薄い細粒の砂碟層 ${ }^{62)}$ からなる段丘面であり，築舘よ り佐沼にかけて広がる高度（海抜 $70 \mathrm{~m}$ ) のよくそ ろった丘陵背面の起源を説明する．また磐井丘陵よ り，迫川の低地にむかって，この段丘面の高度まで なだらかに連なる山稜面があり，これは鮮新統を切 る侵蝕面である.

c）鮮新統の細分にあたった松野 $\left(1967^{27)}\right)$ は, 新田凝灰岩におおわれる砂礫層などを高清水層とし て独立させ，中山層に対比しているが，その下位の 築舘層が磐井丘陵の真瀧層に相当するという見解に 立つものであって，高度を異にする中山層と高清水 層とが必ずしも対比されるとはかぎらない。

d）高位築舘段丘面は，高度が $10 \mathrm{~m}$ 以上であり， 一部に愿い堆積物をともなう。この段丘面の背後の 斜面や，より高位の面は，前沢火山灰層に似た数枚 の黄褐色浮石層におおおれており，この段丘面の堆 積物中にも黄褐色浮石粒がふくまれている.

\section{IV 総括と地形発達史}

a. 段丘面の対比

段丘面の高度と連続により，一部は火山灰層をあ わせて段丘面の対比を行ない，第 2 表にその試案を 示した．高位の段丘面を相互に対比できる火山灰層 は，失なわれたためか認められない。

以上に基ついて推定された基準面の変化は，胆沢 台地においては間歇的低下 ${ }^{63)}$ であり，佐沼低地にお いては波動的低下 ${ }^{6 !}$ である。しかし，胆沢台地と佐 沼低地に打ける基準面変化の phaseは，それぞれ対 応しているようにみえる6ゔ.

b. 小起伏侵蝕面の形成過程

平泉丘陵の，和山段丘面から高度 $200 \mathrm{~m}$ までつゔ く山稜面は，段丘面に起源している．磐井丘陵西部 のよくそろった山稜は，和山段丘面より低く，その 原形は和山段丘面と同じであると予想される。ささて, これらかつてあった平坦面を開析・削剥した基準面 として，次位の一首坂段丘低位面・菅の平面が考え られる．したがって，(1）原面とこれを解体する基 準面の高度の差は小さく，それは最大でも段丘崖の 比高分であり，しかも（2）解体にあずかる谷は，両 地形面の配置に支配されて，比較的長く，勾配は小 さいために, 両者の間に生じた侵蝕面は当然小起伏

61） 1:50,000「涌谷」図幅の地域地質調查にあたった松野の指摘を得て調查した。中新統筑岳層の集塊岩を 複雑に打打う厚さ $30 \mathrm{~m}$ の砂礫層. 無線中継所 $(222 \mathrm{~m})$ を中心に分布し，石仏 $(190 \mathrm{~m})$ や篦岳観音 (232 m) にはみられない. 従来, 中新統をおおうことによって，下部鮮新統とされたものと考えられる。基盤 岩由来の安山岩質の礫をほとんどふくまず，北上山地の古生界由来の粘板岩・砂岩・花崗岩の礫よりなり， 下部では粗大な亜円碟が多く，上部では細粒の，円磨のすすんだ扁平礫が多くなる.

62）前掲 27）はこれを認めていない，下位の高清水層の砂碟層が，新田浮石流凝灰岩にうずめ残された部 分のように解釈しているようにみえるところがある。なお，低位清瀧段丘面とした高度 $30 \sim 40 \mathrm{~m}$ の平坦 面をともなう定高性のよい丘陵頂面についてはひきつづき調査中である.

63）一首坂段丘低位面（しばしば一首坂丘陵と呼ばれる）と胆沢段丘群（上野原面・横道面・堀切面・福原 面は相互の高度の差が小さく，しばしば一括される）との比高がとくに大きい，前掲 54）は，両者の間 の段丘崖を一次的には撓曲崖，二次的には侵蝕崖と考えている。しかし，侵蝕にあずかった基準面の変化 は，前述UI 3.c) の通りである。

64）上述のことに対応して，佐沼低地では高位清瀧段丘面（70m）に先立つ，新田浮石流凝灰岩の基底によ って示される基準面低下期が推定される。すなわち，同浮石流の基底の高度は，築館町付近・瀬峯町東北 新生園付近で $50 \mathrm{~m}$ ，また前掲 27）によれば，梅ガ沢駅付近で20m である。

65）したがって，中流域における段丘面の特色ある配置を生じた地盤運動はあったとしても，各段丘面の段 化には，海水準変動による基準面変化の遡及の効果が働いていると考えられる. 
になる ${ }^{66)}$ と考えられる，また，これら小起伏面が保 存されているのは，その原面および解体にあずかっ た基準面を示す，いずれの段丘面もが未だ保存され ているのとまったく同じ理由によって説明できる.

磐井丘陵東部の富沢面も（1）菅の平面で示される 平坦面があったこと，(2）これを解体する基準面は， 胆沢台地の上野原面などで示されるように，菅の平 面との比高が小さいことによって生じた小起伏侵蝕 面であり，とりわけ (3) 開析谷が遷急点をもって下 流と隔てられたところには，かつてと同じ起伏の減 少作用が続いているといえる ${ }^{67) . ~}$

磐井丘陵から佐沼低地にむかってゆるやかに高度 を低下させる丘陵背面も, 菅の平面やこれより若干 高い西方の侵蝕面が, 高位清瀧段丘面形成以前 ${ }^{68}$ に 侵蝕されて生ビた小起伏面であり, 見かけ上, 同段 丘面に連なっている.

\section{北上山地内の摺沢 ・ 千廐付近の丘陵の地形面は,}

Nakamura $\left(1966^{69}\right)$ によって細分され, 磐井丘陵
の地形面との対比が述べられている (第 2 表)。こ のうち藤沢面は, 盆地底を占める低い丘陵の背面で あり, 高度は240１40m，その一部は若い鮮新統 を切る, 侵蝕面とされている. 盆地を埋める若い鮮 新統 ${ }^{00}$ の上限高度および北上川主流沿いの高位の基 準面が盆地におよんだ高度とが，今後検討される必 要があるが，いずれも200m を大きく上まわること はないと予想される。しかも，これを刻む基準面は， 菅の平面 (140m) に対比されているのであるから， 両者の閒に生じた侵蝕面は当然小起伏になったと考 えられる ${ }^{71}$.

平泉丘陵や磐井丘陵西部では，段丘唯積物とその 下位の油島層のとり去られたところに，厳美層の浮 石質凝灰岩よりなる山棱と, 簃美層の熔結凝灰岩上 りなる谷底との間に小起伏地が形成されている。こ れは厳美層のもともと薄い浮石質凝灰岩層よりなる 山稜が，打そらく透水性に基づく侵蝕抵抗性によっ てよく保存されたためと考えられる。ここでは，熔

66）三野（1942）は，海成段丘面などに起源する等高性丘陵の形成過程の理論的考察を述べている．またこ のような侵蝕面は，規模は小さいが，みかけ上 partial (local) peneplain に相当すると考光られる.すな わち Thornbury（1954）は，Cleland（1928）の報告した鮮新・更新統 Lafayette 層を切る準平原をこの籁 疇に入れている. 三野与吉 (1942) : 地形原論. 古今書院, 401 402.

Thornbury, W. (1954) : Principles of Geomorphology John Wiley and sons, INC., 195 196. Cleland, H. F. (1928) : A pleistocene peneplain in the Coastal Plain Jour. Geol., 28, 102 106.

67）このような小起伏地でも，厚い火山灰が保存されていることはない，たとえば 62 や後述する 221 では稜 線の一部にのみ一枚の浮石層が認められた。 また和山段丘面についても前述III 2.a）の通りである。した がって，このような小起伏地でも，ひきつづき削剝作用がっゔいていることが明らかである。すなわち， Hack (1960，他）のいう dynamic equilibrium の成立した ridge and ravine topographyにあたる。ただ し，現在の丘陵頂面の高度にほぼ近い背面をもって，かつての河床面の背後にあって形成された侵蝕面と して，時間面の意味をもたせることは出来る.

Hack, J. T. (1960) : Interpretation of erosional topography in humid temperate regions Amer. Jour. Sci., Bradley Volume, 258-A, 80 97.

68）新田浮石流凝灰岩の基底は，前掲 64）のように，築舘町付近で $50 \mathrm{~m}$ であり，二迫川以北には分布して いない。よってこの丘陵背面の高度はある範囲内に収まっていた。

69) Nakamura, Y. (1967) : Morphology of the Senmaya Hills in the southern part of the Kitakami mountains. Sci. Rep. Tohoku Univ., 7th Ser. (Geography) 16, 1 18.

70）前掲 20），21）の丸木層. 砂鉄川沿いの盆地および砂鉄川水系と北上川水系との間の低い分水界（丸木， $200+\mathrm{m} ）$ に分布するとされている，盆地内の摺沢から大原にかけては，厚さ $60 \mathrm{~m}$ の砂礫層・砂層よりな る。 その基底高度は $100 \sim 140 \mathrm{~m}$ ，上限は $200 \mathrm{~m}$ までであって，これ以上の丘頂には，風化した花骷岩が露 われている. 下半部の $30 \mathrm{~m}$ は, 粗大な礫・岩塊を混える砂礫層であり, 上半部は細砂と細礫よりなる一 連の互層よりなっている。

71）前掲 69）は，このような小起伏地の形成は, 乾燥気候など, 現在のそれとは異なった侵蝕環境のもと に削剝作用が卓越した結果であると予想を述べている。しかし，ここではその概形を決定した基準面の効 果に関してのみ考察を述べた。 
Table 2 Geomorphological evolution

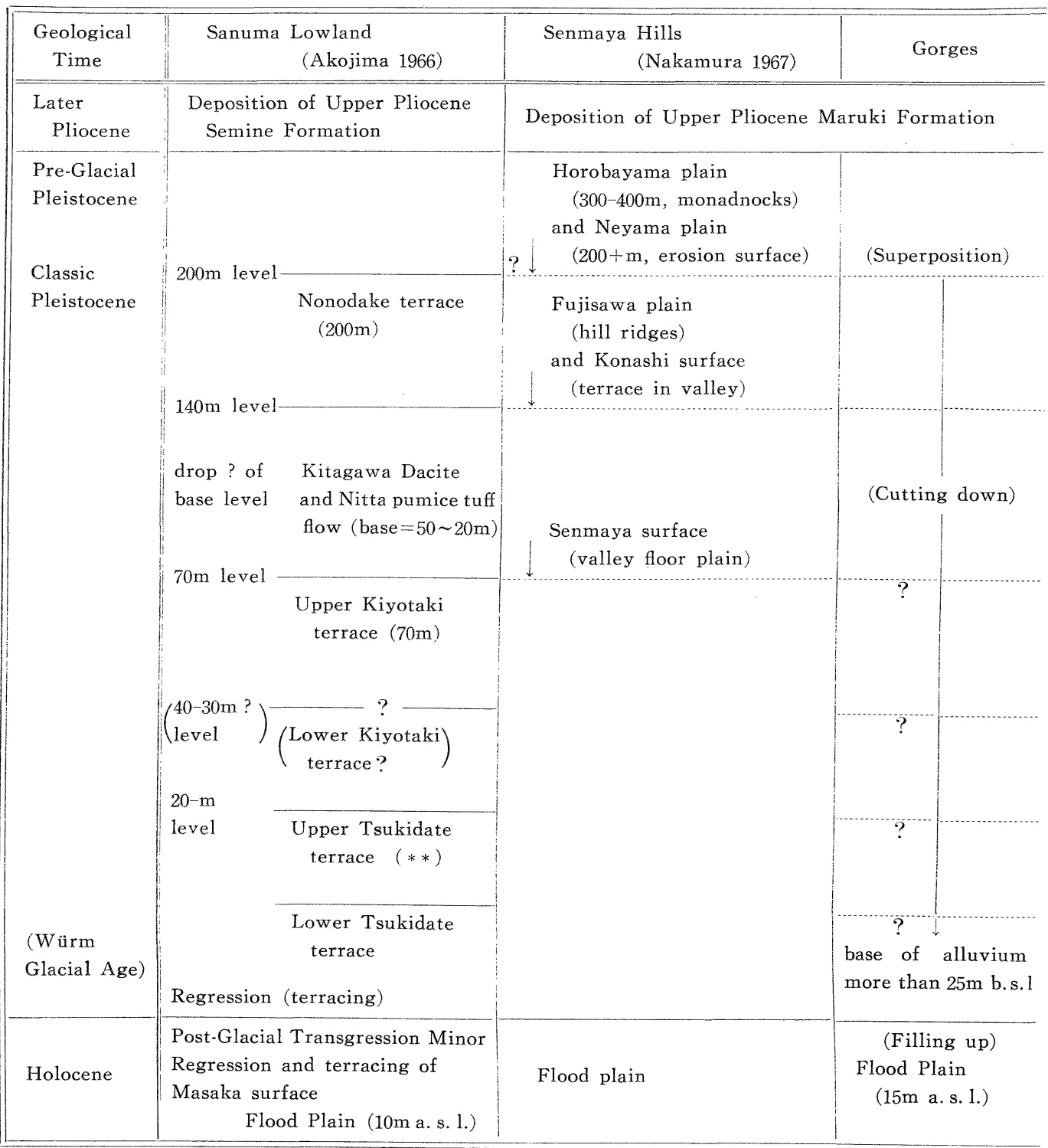

Bars show base levels.

Tephras: * Kurosawajiri volcanic ash

** Maesawa volcanic ash

*** Ishuzaka volcanic ash

Names of Tephras are after Nakagawa et al (1963)

結凝有岩に懸る遷急点が後退したところでも，その

は一首坂段丘低位面形成後, 上野原段丘面形成時ま

前方に，定高性のある山稜と小さな䀣谷とが保存さ での間に生じたことになる ${ }^{72)}$.

れている。しかし, 高度よりみれば, この小起伏地

c. 狐禅寺峡谷の成因

72）ただし，この例は基準面の高度と同層の分布する高度とがたまたま一致したためとみられる。太田川水

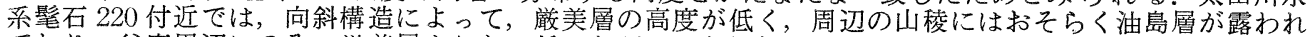
ており, 谷底周辺にのみ, 厳美層よりなる低いなだらかな尾根がみられる。 
of Iwai Hills and environs

\begin{tabular}{|c|c|c|c|}
\hline East Iwai Hills & West Iwai Hills & Hiraizumi Hills & Isawa Upland \\
\hline $\begin{array}{l}\text { Deposition of Mataki } \\
\text { Formation }\end{array}$ & \multicolumn{2}{|c|}{ Relative uplift } & Deposition of Orii Formation \\
\hline & \multicolumn{3}{|c|}{$\begin{array}{l}\text { Piedmont surface of the east flank of the backbone range and possible } \\
\text { deposition of Lower Pleistocene sediments }\end{array}$} \\
\hline (200土m monadnocks?) & (possibly lost) & $\begin{array}{l}\text { Wayama terrace } \\
\quad(200-260 \mathrm{~m})\end{array}$ & $\begin{array}{l}\text { Upper Ishuzaka*,**,*** } \\
\text { terrace }(270-300+\mathrm{m})\end{array}$ \\
\hline $\begin{array}{l}\text { Suganodaira terrace }(140 \mathrm{~m}) \\
\text { Tomisawa surface } \\
\text { (erosion surface) }\end{array}$ & \multicolumn{2}{|c|}{$\begin{array}{l}* * * ? \\
\text { (hill ridges and hanging valleys) }\end{array}$} & $\begin{array}{l}\text { Lower Ishuzaka*,**,*** } \\
\quad \text { terrace }(150 \mathrm{~m} \text { at the lowest) }\end{array}$ \\
\hline & & & \multirow[b]{2}{*}{$\begin{array}{l}\text { Yokomichi terrace*,** }(80 \mathrm{~m} \\
\stackrel{\Xi}{0} \text { at the lowest) } \\
\end{array}$} \\
\hline & & & \\
\hline \multirow[t]{2}{*}{$\begin{array}{l}\text { small terrace on the velley } \\
\text { wall** }\end{array}$} & & & 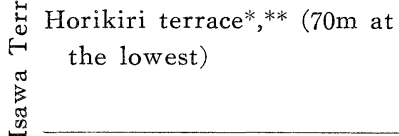 \\
\hline & & & $\begin{array}{l}\text { Hukuhara terrace* }(60 \mathrm{~m} \text { at } \\
\text { the lowest) }\end{array}$ \\
\hline $\begin{array}{l}\text { Hanaizumi terrace } \\
\text { (terracing) }\end{array}$ & $\begin{array}{l}\text { Genbi terrace } \\
\text { (terracing) }\end{array}$ & $\begin{array}{l}\text { Mōtsuzi and } \\
\text { Sehara terraces } \\
\text { (terracing) }\end{array}$ & $\begin{array}{l}\text { Mizusawa terrace } \\
\text { (terracing) }\end{array}$ \\
\hline Flood plain & Flood plain & $\begin{array}{l}\text { Flood plain } \\
\qquad(20 \mathrm{~m} \text { a.s. } 1 .)\end{array}$ & $\begin{array}{l}\text { Flood plain } \\
\quad(30 \mathrm{~m} \text { a. s. } 1)\end{array}$ \\
\hline
\end{tabular}

北上川は磐井丘陵のところで，比較的軟質な地層 よりなるこの丘陵地をさけ，堅硬な古生界の登米粘 板岩や薄衣碟岩を刻んで峡谷をなしている。この峡 谷の成因は古くから注目され，多くの異なった見解 73）田辺健一（1952）：北上川中流狐禅寺峡谷の成因に関する若千の研究. 東北地理，4，35 37.
が述べられているが，とりわけ磐井丘陵頂面の成因 とその形成時期との解䣋を反映して結論を異にして いる。

従来の見解 田辺 $\left(1952^{73)}\right)$ は, 従前の漠とした 
先行谷説に対し，磐井丘陵頂面は北上河谷にみられ る低位侵蝕面 ${ }^{9}$ と一連であるので, 局地的な隆起は 考えられないとし，かつ復旧面図によって，峡谷は より高い地形面に切り込んでいることに注目した。

しかし峡谷内部に台地面に連なる地形面を認めなか ったため「北上山地の山麓面の時代の流路が，船井 丘陵の部分に海が侵入した後, 台地面形成時までの 間に，先行もしくは積載をもたらしていたとは考え られない」としている．また「支谷による争奪や支 谷の蛇行による切断なども考えられない」ので, 古 生界の走向および破砕帯の方向と流路の方向との一 致を示す資料によって，残るところの断層線谷と考 察した。

藤原 $\left(1956,59^{778)}\right)$ は峡谷内部の基盤岩の調査 によって, 流路の方向と断層破砕帯・断層面の最頻 歩向方向とが一致すると述べるとともに, 流路が破 砕帯を選ぶようになった直接の契機こそ注目さるべ きことを強調し, 峡谷内に菅の平面に一連な地形面 が認められることと, 推定された地盤運動によって, 北上川は台地礫層堆積後に北東へ shift したと述べ ている. しかし，台地面より一段と高い古生界より なる孤立峯の向う側へ流路が変換した理由は，とく に述べられていない.

寿円・中川 $\left(1959^{6)}\right)$ は従前の地質資料に従がっ て, 中山層堆積時に峡谷沿いの流路が決定していた

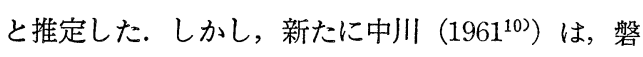
井丘陵頂面は侵蝕面であるとし，その侵蝕にあずか る基準面を与えた峡谷沿いの流路は，これ以前に積 載河川として決定されていたと考えた。また，当時 の基準面高度は，現在の丘陵頂面付近に想定される としているので, 北上川が高度 $224 \mathrm{~m}$ の孤立峯を越 し得た, 最少 $80 \mathrm{~m}$ 厚の積載層がかつてあったこと になる．これは台地磁層の層位を鮮新統に一連のも のとする見解にも関連したように思われる.
考察 峡谷の原形は, 現在の北上川と一連の砂鉄 川沿いに鮮新統が分布している(74)ので，これと同し く, 鮮新世に形成された可能性がある. 鮮新統やそ の上位の地層の埋積の後, 積載河川として, 再び下 刻が始まったのは, 峡谷の両岸の高度からみて, 和 山段丘面形成時を前後する. 菅の平面形成時には, 菅の平面の成因のいずれを問わず，これに連なる河 床面が峡谷内にあるので，すでに峡谷沿いの流路は 決定していた，しかも，菅の平面は中山層の堆積面 と考えられるので，このとき北上川は中山層の堆積 域と峡谷部とに分流していたことになる．このよう な状況は，鮮新世にも恐らくあったであろうし，沖 積世には，下流の佐沼低地において同様の分流が生 じた.

ついで，北上川が峡谷部のみに移った理由として， （1）古北上川の基準面の低下，くわえて，(2) 中 山層堆積域における傾動運動による, 旧河床面の南 部の陸化とせきとめ，もしくは，(3) せまい峡谷沿 いに速やかに下刻がすすみ，争奪を生じたことなど が考えられる，それぞれは対立するものではなく(1) (2)の結果(3)が生じたこともあり得る。このとき下流 側の大泉付近では, 中山層堆積面が徐々に段丘化さ れ75)，北上川河床によって側刻を被ったはずである が，峡谷の急峻な谷壁にこの証拠は残されていない. d. 地形発達史

便宜上，3段階にわけて述べる.

1. 北上河谷の形成・鮮新統の堆積

従来の知見によれば，北上河谷の原形は中新統の 堆積後, 脊梁の隆起にともなって, 脊梁・北上両山 地の山間沈降帯として形成された. ここに下部鮮新 統油島層の海成層や大平層の陸成層が堆積し, ひき つづく脊梁の隆起に参加してこれらは陸化し，国見 山 $(800 \mathrm{~m})$, 大森山 $(350 \mathrm{~m})$ や磐井丘陵西部の丘陵 の基盤岩となった.これにつづく盆地の縮少過程で

74）前掲 70）の丸木層. また真瀧層も，古生界を切る谷を複雑に埋積している（第 3 図-60).

75）中山層の最上部層の一部が，このときの氾濫原堆積物としてもたらされたこともありえよう。 
鮮新統中上部の主な堆積域は, 山間盆地の中央を走 る胆沢一油島撓曲線に沿う地盤運動によって決定さ れた.この鮮新統中上部層は, 亜炭層を挾在する陸 成層を主とし, 以前より陸上で開析過程にあった北 上山地内の一連の小盆地にも分布している.

すなわち，段丘面の複合した広大な胆沢扇状地・ 台地礫層の分布する磐井丘陵東部・低平な丘陵と広 い台地の発達する佐沼低地・小起伏侵蝕面のよく発 達する北上山地内の小盆地群などには若い鮮新統が 分布しており，これらよりやや小高く，主に侵蝕面 よりなる磐井丘陵西部や平泉丘陵には鮮新統下部以 下が分布している．概観すれば，これら丘陵地・台 地の占める地域の広がりは鮮新統の堆積域内に決定 され，その細かな堆積様式の差をもたらした地盤運 動によって，ひきつゔき地形の発達が特徴ゔけられ ている.

\section{2. 最高位段丘の形成}

段丘群の基盤岩のうち最上位の折居層や真瀧層が， 鮮新世以来の堆積盆を満たす一連の地層の最上部を 示すとはかぎらない，最高位の和山段丘面・一首坂 段丘高位面などは，高度 $200 \mathrm{~m}$ 以上にあり，脊梁の 山麓面に切り込んだような分布を示している. 篦岳 丘陵の頂部にある砂礫層の高度も $200 \mathrm{~m}$ である.こ れら最高位の段丘面は, 上部鮮新統の堆積域の縁辺 にある. 北上山地内の揉沢付近の小盆地を埋める鮮 新統の上限高度は $200 \mathrm{~m}$ であり，これをおおう地層 は失なわれたと考えられる.したがって，北上河谷 を埋め，脊梁の山麓面に連なる，おそらく第四紀前 半にかかる最上位の堆積物は，これらの段丘面の形 成の過程で失なわれたものと解される.

3. 基準面変化と段丘群・低位侵蝕小起伏面群の 形成

最高位の段丘面に次いで，北上川沿いに中山層が 広く堆積し，胆沢川治いに一首坂段丘低位面が胆沢
台地の広がりの全体を占めた時 ${ }^{76)}$ ，これらの河床面 の背後では, 上位の段丘面を㔻食して小起伏面が形 成された. すなわち, 磐井丘陵では, 中山層の堆 積面 (菅の平面) が丘陵背面として想定できる（周 辺にこれと比高の小さな河間地を伴なっている),一 方，撓曲線をへだてた西方には，少なくともこれよ り若干高い侵蝕面が現在も残っている. 北上山地内 の盆地でも同様にして小起伏面が生じた.

ひきつづく基準面の間歇的な低下と地盤運動によ って，胆沢川沿いに順に北側に配列する段丘群が形 成された．胆沢台地のそれぞれの河床面は順次縮少 し，北上川本流もせまい峡谷を通じて排水されるよ ろになった. 北上川本流の基準面に対応して，胆沢 台地を刻む必従川および名残り川である，北上川支 流沿いに段丘が形成され，また陸化したかつての北 上川河床面（菅の平面）は，侵蝕・解体されて小起 伏面（富沢面）を生じた.このとき磐井丘陵の南半 部（菅の平面およびその西方の侵蝕小起伏面）は， 迫川水系の南へむかう支谷と東へむから金流川水系 の小谷によって解体され，高度 $140 \mathrm{~m}$ 以下の丘陵頂 面が形成された．金流川水系の小谷の一部は後に迫 川水系に奪われて抢り，金流川水系と迫川水系の間 の分水界は，現在非常に入りくんだ形を示している. しかし，金流川沿いの谷壁の一部に，前沢火山灰に おおわれる段丘面77や斜面があるので，現在みられ る丘陵頂面は，ほぼ当時の高度を保っているといえ る.

平泉丘陵や磐井丘陵西部では, 侵蝕の過程で浮石 質凝灰岩と熔結凝死岩（箃美層）が露われたとき, 小起伏地が形成されやすく, 基準面低下後も小起伏 地がひきつづき保存されている.

Würm 氷期に至ると，金流川沿いには花泉段丘 面が磐井川沿いには敩美段丘面が，北上川本流沿い には水沢段丘面が，現在の谷底面の広がりの全体を

76）胆沢台地の内部に残丘として（202，206），また胆沢川の北岸にも同一高度の地形面がある.

77）前掲 43）において，支谷中に，花泉段丘面やその上位の段丘面のそれぞれに連なる懸谷状の谷底面が 報告されている. 
占めていた.これらの段丘面が段丘化されたのは， 海水準低下の遡及の直接の効果によるものと推定さ れた。このとき峡谷は $40 \mathrm{~m}$ 以上下刻された。

これに次ぐ, 後水期の海水準上昇によって峡谷は 埋積がすすみ，佐沼低地では入り組んだおぼれ谷地 形が生じた。
繩文時代後期の小海退にともなって，沖積低地面 の一部（迫川沿いの真坂面）は段丘化された.

この研究は, 東北大学理学部 西村嘉助・能 登志雄 両教授をはじめ, 地理学教室の諸先学の方々の御指導の 下に行なった. また, 東北大学工学部庄司力偉助教授, 東北大学理学部中川久夫氏, 地質調査所松野久也氏, 岩 手県立一関第一高等学校小野寺信吾氏には, それぞれ御 教示いただいた．記して感謝の意を表します。

(1969 年 5 月 19 日 受理)

\section{GEOMORPHOLOGY OF IWAI HILLS AND ENVIRONS}

\section{Isao AKOJIMA*}

The erosion surfaces are generally recognized as accordant summit levels or undulating surfaces, the origin or the development process of which, I think, is not clearley explained. The development process of Iwai Hills, which are in the Kitakami Valley area between Kitakami Mountains to the east and Ōu backbone range to the west and are dividing the Kitakami Valley area into the northern middle reaches and the southern lower reaches, is discussed here as an example of erosion surfaces. The hills were once considered as a part of so called 'Rikuzen peneplain'.

According to previous researches on geohistory of the Kitakami Valley area, the valley area was determined by the distribution area of Lower Pliocene sediments in the inter-mountain basin between Kitakami Mountains and $\overline{\mathrm{O} u}$ backbone range which had been uplifting since Miocene.

The Isawa-Yushima line of flexture runs north to south in the center of the valley area, and the distribution of Middle and Upper Pliocene sediments and Upland Gravels of Iwai Hills is delimited to the east of the line, and it appeared as the dislocation of the terraces of Isawa Upland, north of Iwai Hills.

The formation of erosion surfaces is related with the change of base level around the area (Table 2), and the process is summarized as follows;

\section{Description of the erosion surfaces and the terrace surfaces}

The erosion surfaces of West Iwai Hills, western half of Iwai Hills, and of Hiraizumi Hills situated between Iwai Hills and Isawa Upland are between the highest terraces and the next ones in height. The highest terraces such as the Upper Ishuzaka terrace of Isawa Upland, the Wayama terrace of Hiraizumi Hills and the Nonodake terrace to the south of Sanuma Lowland are at the margin of Middle and Upper Pliocene sedimentary basin overlying the Miocene and Lower Pliocene sediments, and their height are 200 meters above sea level at the border of the Kitakami river and the lowland. The terrace deposits of these terraces were almost worn away. The first two are cutting into the east flank of the backbone range, and there Uppermost Pliocene and Lower Pleistocene sediments fringing the range 
were perhaps lost.

The next terraces are the Lower Ishuzaka terrace (less than $150 \mathrm{~m}$ at the lowest) of Isawa Upland and the Suganodaira terrace (130 to $140 \mathrm{~m}$ ) of East Iwai Hills, eastern half of Iwai Hills. The Lower Ishuzaka terrace has a wide surface and thick terrace deposits covered with volcanic ash and pumice fall. The Suganodaira terrace has no wide and flat surface, and the hill ridges of East Iwai Hills make an undulating erosion surface (Tomisawa surface) cut into the Nakayama Formation, the upland gravels and its bedrocks. The restored summit level (Suganodaira surface) shows that the accordant hill tops are depositional or erosional in origin according to the interpretation of the age of the Nakayama Formation, that is, the interpretation of the time gap of the contact between the formation and the underlying Pliocene Mataki Formation.

The Suganodaira surface is concluded to be a fill top terrace surface based on the following facts ;

a) Accordance of the restored summit level (fig. 1).

b) The coincidence of the Suganodaira surface with the distribution of the Nakayama Formation and partly with the low interfluves (fig. 1).

c) The Nakayama Formation is consisting of fluvial sediments of 40 meters in thickness at maximum, sand and gravel $(10 \mathrm{~m})$ at the base and clay and cross-laminated sand at middle and upper beds (fig. 3).

d) The base of the Nakayama Formation has valley form matched with the geological structure of bedrocks underlying it perhaps in discomformity (fig. 4).

e) No deposits cover the Nakayama Formation, and the upper member may be flood plain sand and silt.

f) The Nakayama Formation is sheet typed, which is as wide as the present Kitakami river plain (fig. 1).

g) Both the Suganodaira surface and the Nakayama Formation base slope down northward, but the directions of paleocurrent in the Nakayama Formation are wholly southward (fig. 6). This means the Suganodaira surface tilted northward after the upland gravels had deposited. The drainage pattern is well matched with the Nakayama Formation base. The slope of the Suganodaira surface is not explained by the differential erosion of different base levels of tributaries.

h) The Suganodaira surface and the Lower Ishuzaka terrace are to be correlated each other when the displacement of the Suganodaira surface is restored.

i) Therefore, the time gap of discomformity between the Nakayama Formation and the underlying Pliocene Mataki Formation may be great.

Based on the above mentioned facts, it is concluded that the erosion surfaces of West Iwai Hills and Hiraizumi Hills are originated from the highest terraces and are beveled to the base level of the next terraces, such as the Lower Ishuzaka terrace and the Suganodaira terrace, enclosing the upper ones, and that the erosion surface of the Tomisawa surface is originated from the flat fill top surface of the Suganodaira surface.

Since the Suganodaira surface had been terraced with the drop of base level, the Kitakami 
river changed the course eastward and drained through narrow gorges. Then the base level dropped intermittently in the middle reaches, but fluctuatingly in the lower reaches on the coastal lowland. But the terraces of Isawa Upland in the middle reaches and the terraces of Sanuma Lowland in the lower reaches are correlated by the height and the phase of change of base level considering the upstream extending effect of base level fluctuation, and partly by the tephra key beds.

The Tomisawa surface is continuing in height down to the Isawa terraces (the Uenohara terrace, $90 \mathrm{~m}$ at the lowest, and others) in the north and to the Upper Kiyotaki terrace $(70 \mathrm{~m})$ in the south. Therefore, the base levels to which the Suganodaira have been eroded into the Tomisawa surface are shown by the Isawa terraces in the north and by the base of the Nitta pumice tuff flow, the bedrock of the Upper Kiyotaki terrace in the south. And the original heights of the Tomisawa surface remain and in the valley dissecting the Tomisawa surface, lower small terraces are hanging.

\section{The formation process of the erosion surfaces}

It is impossible to find out any evidence for that the erosion surfaces described above are formed by lateral erosion of the valleys cutting into the upper surfaces.

For an understanding of these undulating erosion surfaces formation;

(a) there had been flat terrace surface, and then (b) it was dismantled and dissected to the next lower base level by the long and gentle profiled, consequent valleys running under the control of terrace arrangement. Therefore, the erosion surface was beveled in the limited height ranging between the upper one and the lower one, and especially (c) the undulating surface in the core area might be well preserved, where protected by hard rocks from the rejuvenation (fig. $7-\mathrm{A}$ ).

Younger Pliocene sediments filling in small basins such as along the Satetsu river in Kitakami Mountains of Paleozoic rocks are not distributed higher than $200 \mathrm{~m}$ and are cut by erosional undulating surface to $140 \mathrm{~m}$ base level of the Suganodaira surface in the Kitakami Valley area.

(d) In West Iwai Hills and Hiraizumi Hills, where the terrace deposits and underlying Pliocene sediments had been worn out, undulating surfaces were cut at the height between the low and flat fidges composed of pumice tuff bed of Miocene Genbi Formation and the hanging valley floor of welded tuff bed of the formation. (fig. 7-B). It may be resulted from the resistance against erosion due to permeability of the pumice tuff preserving the original small thickness between the ridges and the valley bottoms. 